Proc. Estonian Acad. Sci. Biol. Ecol., 2001, 50, 1, 5-13

\title{
CHANGES IN THE TEXTURE AND EXCHANGE PROPERTIES OF SKELETAL QUARRY DETRITUS UNDER FOREST DURING THIRTY YEARS
}

\author{
Loit REINTAM
}

Institute of Soil Science and Agrochemistry, Estonian Agricultural University, Viljandi mnt., Eerika, 51014 Tartu, Estonia

Received 13 December 2000

\begin{abstract}
Areas of former open-cast oil-shale mines afforested about 30 years ago were studied at Sirgala, NE Estonia. Synchronously with the development of high productivity pine stands, a rapid progress of Calcaric Regosol has taken place on pure skeletal (450-650 g kg-1 of skeleton) quarry detritus. Organic carbon of the $\mathrm{R}_{2} \mathrm{O}_{3}$-humic-fulvic forest humus of litter and root origin amounts to $28 \pm 6 \mathrm{~g} \mathrm{~kg}^{-1}$ in the epipedon formed and to $13 \pm 3 \mathrm{~g} \mathrm{~kg}^{-1}$ in the transitional AC-horizon. The proportion of humus compounds bound with clay and immobile sesquioxides is also significant. Forest humus is active and the soluble fractions make up $60-80 \%$ of total organic carbon. Interactions between the formed humus and the mineral stratum of detritus have resulted in the weathering of stone, gravel, and sand fractions and in the accumulation of clay in the epipedon and of silt in the transitional horizon. Subsequent physical and further chemical weathering, progressing in depth, are characteristic of any fraction. The territorial (site) variability of changes in texture is lower than in the composition of organic pedogenetic agents. $\mathrm{Ca}^{2+}$ forms more than $80 \%$ of base exchangeable capacity, the proportion of $\mathrm{Mg}^{2+}$ being highly variable. Humus colloids are prevalent in the exchange complex although the formed clay is also important.
\end{abstract}

Key words: quarry detritus, primary pedogenesis, soil texture, exchangeable properties, Calcaric Regosol.

\section{INTRODUCTION}

Pedogenesis on any crust of weathering can start after the development of a permanent plant cover on it. Quarry detritus represents the parent material for soil formation in areas of open-cast mining of mineral resources and/or fossil fuels. Interactions between mineral detritus and the formed plant cover have been studied and described for several ecological situations (Taranov \& Komissarov, 1974; Makhonina, 1974, 1979; Schafer et al., 1980; McSweeney \& Jansen, 1984; Uzhegova \& Makhonina, 1984; Roberts et al., 1988; Fedorets et al., 1998; Rumpel et al., 1998). 
In North-East Estonia, rehabilitation of the skeletal calcareous detritus of open-cast oil-shale mining for forestry purposes has been carried out in an area of over 8000 ha since 1960. Ordinary and dolomitized Ordovician limestones contain $60-70 \%$ of detritus, making it highly coarse and calcareous. A survey of silvicultural properties of detritus as well as the first results of forest rehabilitation on quarry detritus were published in the early 1970s (Vaus, 1970, 1975; Kaar et al., 1971). As it was prognosticated already in the early 1960s, afforestation of quarry detritus with 2-3-year sets proved to be highly effective (Kaar, 1968, 1998). Normally functioning forest ecosystems developed everywhere. The soils formed on pure detritus during 29-35 years were studied at Kohtla and Viivikonna to ascertain the character and capacity of pedogenesis (Reintam \& Kaar, 1999). The formation and progress of soil organic matter under pine were studied at Sirgala (Reintam et al., 2000).

This study deals with changes in the texture and exchange properties of forest soils under pine stands that have developed from sets synchronously with the formation and development of the entire forest-soil system.

\section{MATERIAL AND METHODS}

Five areas at Sirgala $\left(27^{\circ} 47^{\prime}\right.$ E, $\left.59^{\circ} 19^{\prime} \mathrm{N}\right)$, afforested in $1965-70$ with twoyear sets of Scots pine (Pinus sylvestris), were investigated. The formed genetic horizons (A-AC-BC) were studied, described, and sampled to a depth of 20-25 cm where signs of pedogenesis were already evident. A well-known methodology of soil science was applied. The stands (Photo 1) were surveyed in circular areas of 0.05 ha each by Elmar Kaar. Milled dry falling litter and ground litter, and fine earth with a particle size less than $2 \mathrm{~mm}$ were analysed. Samples for the determination of particle size were treated with sodium pyrophosphate to break down aggregates. Sands were sieved and fractions finer than $0.05 \mathrm{~mm}$ were determined by pipette analysis (Pipette Apparatus Table Model 7 Samples). Base exchange capacity (BEC) and exchangeable bases were measured by percolation of the samples with ammonium acetate at $\mathrm{pH} 7.0$ and expressed in $\mathrm{cmol} \mathrm{kg}^{-1}$. The total amounts of organic carbon and nitrogen were measured by the Tyurin and Kjeldahl volumetric methods, respectively. It is necessary to point out that the Anne method (Ranst et al., 1999) is equivalent to the Tyurin method used. The organic $\mathrm{C}$ and $\mathrm{N}$ of oil shale (kukersite) that were present in detritus (14.4-19.7 $\mathrm{g} \mathrm{kg}^{-1}$, in one profile even $44.5 \mathrm{~g} \mathrm{~kg}^{-1}$ ) were subtracted from the obtained values when the composition of organic matter of plant origin was calculated.

The group and fractional composition of humus was determined by an alternate acid-alkaline treatment using the Tyurin-Ponomareva volumetric method (Ponomareva, 1957). The obtained results were expressed in percentages of organic carbon of plant (forest) origin. 


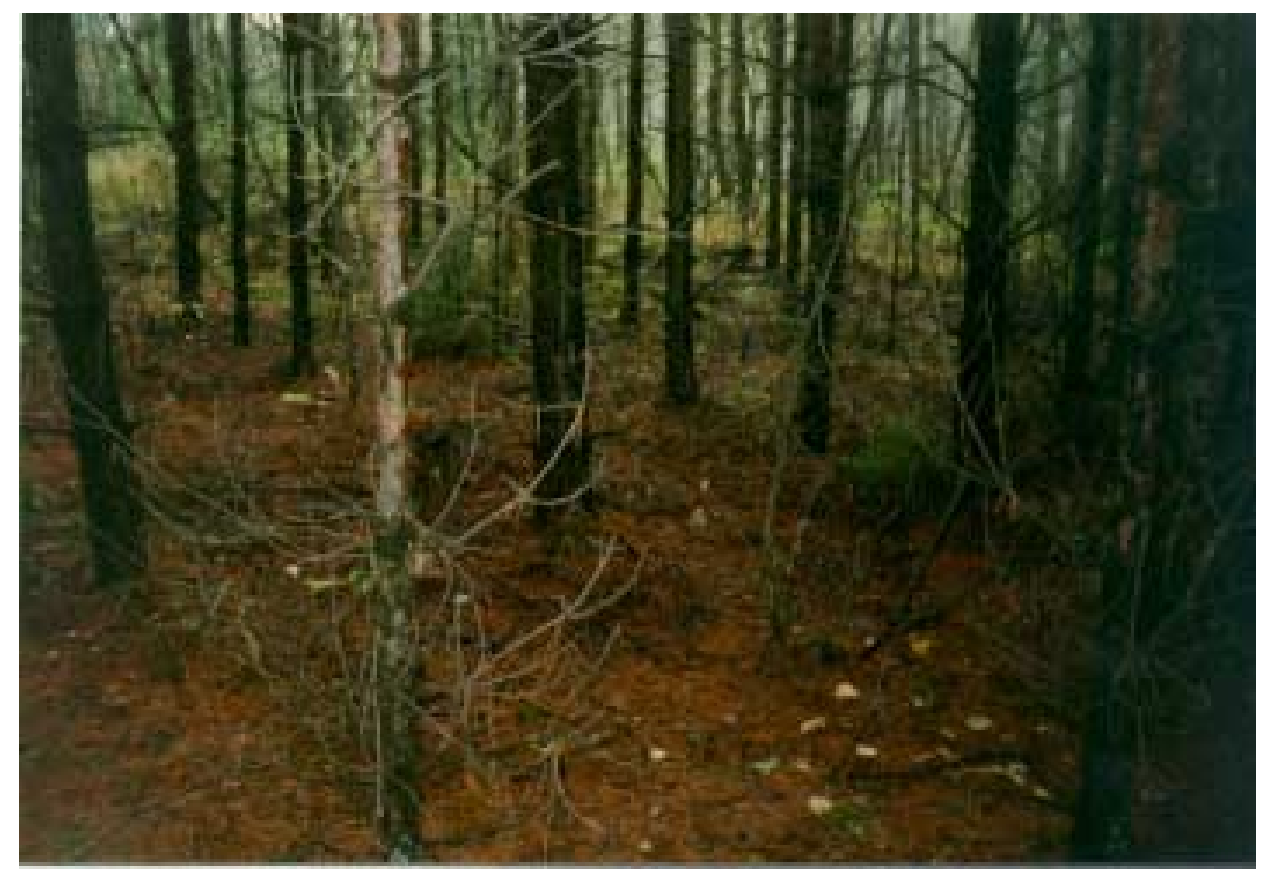

Photo 1. A 30-year-old pine stand with permanent forest ground litter.

All the studied samples represented an average of different parts of the horizons. Requirements for the accuracy of laboratory techniques and measurements were satisfied. All obtained data were statistically processed; the arithmetic mean $(\bar{x})$, standard error of the mean $\left(s_{\bar{x}}\right)$, and the coefficient of variation $(V, \%)$ are presented.

\section{RESULTS AND DISCUSSION}

In about 30 years a brownish black (10YR2/2) A-horizon with a thickness of $9.4 \pm 1.5 \mathrm{~cm}$ had appeared everywhere (Photo 2 ). A very dark greyish brown (10YR3/2) AC-horizon with a thickness of $12.2 \pm 1.2 \mathrm{~cm}$ had deepened to a depth of $20-25 \mathrm{~cm}$. The dark colour can be partly ascribed to the oxidized remains of kukersite in the composition of the insoluble residue. Falling litter and ground litter of Moder type had already differentiated. The average annual increase in the growing stock of stands during about 30 years was $2.4-7.4 \mathrm{~m}^{3} \mathrm{ha}^{-1}$ in different areas, the average annual increase in height was $25-40 \mathrm{~cm}$ and in breast-height diameter $0.2-0.4 \mathrm{~cm}$ (Reintam et al., 2000). Such high productivity of forest has resulted in the formation of permanent falling litter, in which the contents of organic carbon and nitrogen are $499.6 \pm 13.1$ and $8.8 \pm 1.9 \mathrm{~g} \mathrm{~kg}^{-1}$, 


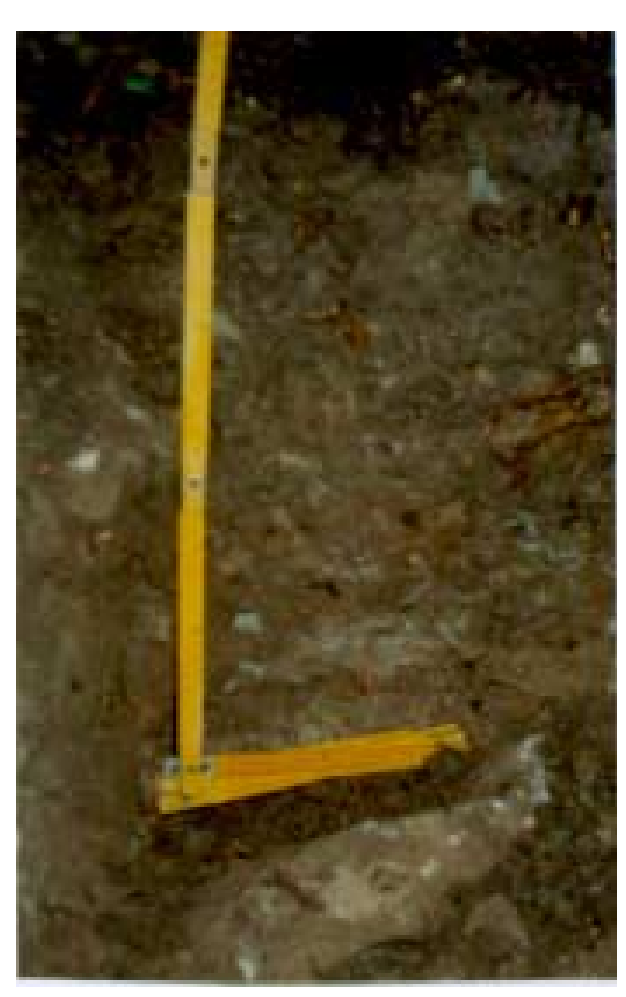

Photo 2. A 31-year-old section (O2-A-ACBC-C) of Calcaric Regosol under a pine stand in a parcel without grasses. respectively. As $\mathrm{N}$-fixators are lacking, the content of nitrogen is almost nine times as variable $(V=43 \%)$ as that of organic carbon $(V=5 \%)$. A large $\mathrm{C}: \mathrm{N}$ ratio $(57 \pm 12)$ is characteristic of falling litter. Its transformation results in an increase in nitrogen both in ground litter and in the primary epipedon formed (Table 1). Although this increase seems to be biogenic in origin, atmospheric deposition cannot be excluded either, as was the case in an industrial region of France (Thimonier et al., 2000). When the $\mathrm{C}: \mathrm{N}$ ratio decreases a decrease takes place also in its variability. As native ground litter favours increase in transformation rates of falling litter in the formation of the organic pool of the forest floor (Chadwick et al., 1998), further trends of organic-mineral interactions in the solum depend on the organic matter derived from ground litter (Bogatyrev et al., 1998). Humus of $\mathrm{R}_{2} \mathrm{O}_{3}$-humic-fulvic nature is active everywhere (Table 1 ) and can have an impact on the mineral stratum. Ca-humic-fulvic complexes are absent in many cases, as a result of which their proportion is highly variable, and interactions between organic and mineral substances may be favoured. Since residual kukersite has been humified in the composition of the insoluble fraction (Reintam et al., 2000) it cannot influence biological weathering.

Against the background of a relatively variable humus status, pedogenetic changes in texture appear to be more or less uniform (Table 2). Weathering of sand-size fractions has resulted in the formation and accumulation of clay in the thin A-horizon and of silt beneath it in the transitional AC-horizon. The distribution of the skeleton within only some 20 or $30 \mathrm{~cm}$ indicates the physical break-up of small stones from top, while an upward decrease in the quite uniform stoniness is significant for the sites studied. Pedogenetic weathering is gradually progressing in depth involving ever finer fractions. The ratios between the pools of fractions suggest simultaneous changes not only in the initial size of components of detritus, but also in particles that have formed in the process of contemporary crumbling in situ. A similar situation was described from Vosges, France (Fichter et al., 1998). Depending on the variability of ground vegetation 
Table 1. Composition of plant humus in percentages of organic carbon

\begin{tabular}{|c|c|c|c|c|c|c|}
\hline \multirow[t]{2}{*}{ Characteristic } & \multicolumn{2}{|c|}{ Ground litter $(n=9)$} & \multicolumn{2}{|c|}{ A-horizon $(n=5)$} & \multicolumn{2}{|c|}{ AC-horizon $(n=5)$} \\
\hline & $\bar{x} \pm s_{\bar{x}}$ & $V, \%$ & $\bar{x} \pm s_{\bar{x}}$ & $V, \%$ & $\bar{x} \pm s_{\bar{x}}$ & $V, \%$ \\
\hline Organic $\mathrm{C}, \mathrm{g} \mathrm{kg}^{-1}$ of soil & $322.0 \pm 22.6$ & 20 & $28.2 \pm 6.0$ & 47 & $12.8 \pm 3.4$ & 60 \\
\hline Nitrogen, $\mathrm{g} \mathrm{kg}^{-1}$ of soil & $9.0 \pm 1.0$ & 30 & $1.7 \pm 0.3$ & 18 & $1.2 \pm 0.2$ & 35 \\
\hline $\mathrm{C}: \mathrm{N}$ & $35.8 \pm 3.6$ & 28 & $16.6 \pm 1.8$ & 24 & $10.7 \pm 1.4$ & 28 \\
\hline Humic acids (HA): 1 & $6.3 \pm 0.6$ & 25 & $8.5 \pm 1.0$ & 25 & $11.4 \pm 2.2$ & 43 \\
\hline 2 & $1.9 \pm 1.2$ & 174 & $5.7 \pm 3.9$ & 155 & $1.9 \pm 1.7$ & 200 \\
\hline 3 & $2.2 \pm 0.5$ & 59 & $4.5 \pm 2.0$ & 100 & $2.1 \pm 1.2$ & 124 \\
\hline$\Sigma$ & $10.4 \pm 2.0$ & 54 & $18.7 \pm 4.3$ & 52 & $15.4 \pm 3.5$ & 50 \\
\hline Fulvic acids (FA):1a & $1.6 \pm 0.2$ & 37 & $6.5 \pm 1.6$ & 56 & $5.4 \pm 2.5$ & 105 \\
\hline 1 & $10.3 \pm 0.7$ & 18 & $9.9 \pm 3.0$ & 68 & $12.1 \pm 2.7$ & 51 \\
\hline 2 & $1.9 \pm 0.9$ & 137 & $13.1 \pm 4.3$ & 74 & $11.6 \pm 5.8$ & 112 \\
\hline 3 & $1.6 \pm 0.5$ & 87 & $5.3 \pm 2.0$ & 82 & $9.0 \pm 1.0$ & 25 \\
\hline$\Sigma$ & $15.4 \pm 1.4$ & 26 & $34.8 \pm 3.8$ & 25 & $38.1 \pm 8.2$ & 48 \\
\hline $\begin{array}{l}\text { Hydrolysate of } 0.5 \mathrm{M} \\
\mathrm{H}_{2} \mathrm{SO}_{4}\end{array}$ & $5.5 \pm 0.6$ & 31 & $10.5 \pm 1.6$ & 34 & $20.1 \pm 5.9$ & 66 \\
\hline Total soluble & $31.3 \pm 2.6$ & 24 & $64.0 \pm 6.7$ & 24 & $73.6 \pm 12.2$ & 37 \\
\hline Insoluble & $68.7 \pm 2.6$ & 11 & $36.0 \pm 6.7$ & 42 & $26.4 \pm 12.2$ & 103 \\
\hline HA : FA & $0.68 \pm 0.18$ & 37 & $0.53 \pm 0.10$ & 41 & $0.41 \pm 0.10$ & 55 \\
\hline
\end{tabular}

Table 2. Texture of fine earth in $1999, \mathrm{~g} \mathrm{~kg}^{-1}$

\begin{tabular}{|c|c|c|c|c|c|c|}
\hline \multirow[t]{2}{*}{ Fraction } & \multicolumn{2}{|c|}{ A-horizon $(n=7)$} & \multicolumn{2}{|c|}{ AC-horizon $(n=9)$} & \multicolumn{2}{|c|}{ BC-horizon $(n=6)$} \\
\hline & $\bar{x} \pm s_{\bar{x}}$ & $V, \%$ & $\bar{x} \pm s_{\bar{x}}$ & $V, \%$ & $\bar{x} \pm s_{\bar{x}}$ & $V, \%$ \\
\hline $\begin{array}{l}\text { Skeleton }(>2 \mathrm{~mm}) \mathrm{g} \mathrm{kg}^{-1} \\
\quad \text { in soil }\end{array}$ & $350 \pm 24$ & 18 & $430 \pm 52$ & 24 & $520 \pm 36$ & 15 \\
\hline $2-0.5 \mathrm{~mm}$ & $133 \pm 13$ & 27 & $120 \pm 10$ & 16 & $175 \pm 25$ & 32 \\
\hline $0.5-0.25 \mathrm{~mm}$ & $125 \pm 5$ & 10 & $111 \pm 9$ & 16 & $115 \pm 8$ & 16 \\
\hline $0.25-0.05 \mathrm{~mm}$ & $260 \pm 25$ & 25 & $255 \pm 37$ & 29 & $242 \pm 25$ & 23 \\
\hline $0.05-0.002 \mathrm{~mm}$ & $398 \pm 27$ & 18 & $439 \pm 46$ & 21 & $396 \pm 29$ & 17 \\
\hline$<0.002 \mathrm{~mm}$ & $84 \pm 12$ & 37 & $75 \pm 6$ & 16 & $72 \pm 3$ & 11 \\
\hline $\begin{array}{l}\text { Coarse \& medium } \\
\text { sand : fine sand }\end{array}$ & \multicolumn{2}{|c|}{1.0} & \multicolumn{2}{|c|}{0.9} & \multicolumn{2}{|c|}{1.2} \\
\hline Sand : silt & \multicolumn{2}{|c|}{1.3} & \multicolumn{2}{|c|}{1.1} & \multicolumn{2}{|c|}{1.3} \\
\hline Silt : clay & \multicolumn{2}{|c|}{4.7} & \multicolumn{2}{|c|}{5.8} & \multicolumn{2}{|c|}{5.5} \\
\hline $\begin{array}{l}\text { Specific surface area, } \\
\qquad \mathrm{m}^{2} \mathrm{~g}^{-1}\end{array}$ & $60 \pm 11$ & 50 & $38 \pm 9$ & 45 & $26 \pm 4$ & 34 \\
\hline
\end{tabular}


and active humic-fulvic agents, a somewhat higher variability of fine sand in the AC-horizon demonstrates the dynamic status of this fraction in the process of subsequent weathering (Table 2). The specific surface area has increased about twofold for the thin epipedon, which is a consequence of a synchronous increase in its humousness and clay content.

Table 3. Base exchange capacity, $\mathrm{cmol} \mathrm{kg}^{-1}$

\begin{tabular}{l|c|c|c|c|c|r|r|r}
\hline \multirow{2}{*}{ Cation } & \multicolumn{2}{|c|}{ Forest floor $(n=10)$} & \multicolumn{2}{c|}{ A-horizon $(n=5)$} & \multicolumn{2}{c|}{ AC-horizon $(n=5)$} & \multicolumn{2}{c}{ BC-horizon $(n=5)$} \\
\cline { 2 - 9 } & $\bar{x} \pm s_{\bar{x}}$ & $V, \%$ & $\bar{x} \pm s_{\bar{x}}$ & $V, \%$ & $\bar{x} \pm s_{\bar{x}}$ & $V, \%$ & $\bar{x} \pm s_{\bar{x}}$ & $V, \%$ \\
\hline $\mathrm{Ca}^{2+}$ & $54.7 \pm 5.7$ & 31 & $23.3 \pm 0.7$ & 12 & $15.6 \pm 0.5$ & 11 & $13.6 \pm 0.3$ & 8 \\
$\mathrm{Mg}^{2+}$ & $8.9 \pm 1.7$ & 58 & $5.9 \pm 0.7$ & 46 & $3.4 \pm 0.6$ & 67 & $1.9 \pm 0.2$ & 48 \\
$\mathrm{~K}^{+}$ & $1.4 \pm 0.2$ & 36 & $0.3 \pm 0.01$ & 23 & $0.2 \pm 0.0$ & 0 & $0.2 \pm 0.01$ & 35 \\
$\mathrm{Na}^{+}$ & $0.3 \pm 0.03$ & 33 & $0.1 \pm 0.01$ & 50 & $0.1 \pm 0.0$ & 0 & $0.1 \pm 0.0$ & 0 \\
& & & & & & & & \\
Total & $65.3 \pm 6.7$ & 30 & $29.6 \pm 1.1$ & 15 & $19.3 \pm 0.9$ & 19 & $15.8 \pm 0.4$ & 9
\end{tabular}

Although humus substances play an important role in the formation of the exchange complex (Table 3), the formed clay is also essential in topsoil. Calcium accounts for $79-87 \%$ of BEC, and its amount in detritus and the soil horizons formed is highly uniform. Uniformity is also characteristic of total BEC there, although the proportion of magnesium shows high variability in places. The higher variability of the exchange properties in the forest floor seems to be due to the variability of ground vegetation, and it is accompanied with differences both in the degree of humification and in the composition of forest humus. As to exchangeable bases, the studied primary Calcaric Regosols are accumulative, like primary soils everywhere (Beschow et al., 2000). No recent losses were established as it was described for a beech stand in France (Thimonier et al., 2000). All the studied soils on quarry detritus are characterized by alkaline reaction ( $\mathrm{pH}$ 6.7-7.6) and complete absence of exchange acidity. Even falling litter ( $\mathrm{pH} 4.7-5.1)$ and the forest floor ( $\mathrm{pH} 5.4-6.0)$ are only slightly acid.

\section{CONCLUSIONS}

$\mathrm{R}_{2} \mathrm{O}_{3}$-humic-fulvic forest humus, derived mostly from the moderately transformed ground litter of Moder type, represents an agent for organic-mineral interactions and pedogenesis on the skeletal calcareous quarry detritus of opencast oil-shale mining. As a result of the physical weathering of coarse particles and subsequent pedogenetic changes in products, the textural status is characterized by an accumulation of clay in the thin humus horizon and of silt beneath it. Against the background of the relatively variable composition of 
humus, the variability of changes in the texture of quite uniform detritus is insignificant. An upward increase in specific surface area and base exchange capacity indicates the accumulative character of pedogenesis. The highly prevalent $\mathrm{Ca}^{2+}$ in the exchange complex appears to be sufficient for saturating the biological turnover of substances but insufficient for the formation of stable humic-fulvic complexes bound with alkaline earths.

The Calcaric Regosols formed within some 30 years are close to Rendzic Leptosols, while their epipedon is very close to the mollic. Development of cambic properties is already evident, and synchronicity of highly intensive production and pedogenetic processes was demonstrated.

\section{ACKNOWLEDGEMENTS}

This study was supported by the Estonian Science Foundation grant No. 4090. I would like to thank Mrs. Raja Kährik, research assistant, who carried out all laboratory analyses, as well as Elmar Kaar and Igna Rooma for help in field activities. Thanks are due to Mrs. Ester Jaigma for the linguistic revision of the manuscript.

\section{REFERENCES}

Beschow, H., Gransee, A. \& Merbach, W. 2000. Soil development on loess substrate in central Germany - results of a long-term trial on soil formation. J. Plant Nutr. Soil Sci., 163, 359366.

Bogatyrev, L. G., Svenitskii, I. A., Sharafutdinov, R. N. \& Stepanov, A. A. 1998. Forest litters and the diagnostics of the modern trend in humus formation in different geographical zones. Pochvovedenie (Eurasian Soil Sci.), 7, 864-875.

Chadwick, D. R., Ineson, P., Woods, C. \& Piearce, T. G. 1998. Decomposition of Pinus sylvestris litter in litter bags: Influence of underlying native litter layer. Soil Biol. Biochem., 30, 47-55.

Fedorets, N. G., $\quad$ Shil'tsova, G. V., Germanova, N. I., Antipina, G. S., $\quad$ Kryshen', A. M. ～\& Sokolov, A. I. 1998. Initial stages of soil formation on the tailings of an iron-ore deposit in the subzone of northern taiga in Karelia. Pochvovedenie (Eurasian Soil Sci.), 2, 133-139.

Fichter, J., Turpault, M.-P., Dambrine, E. \& Ranger, J. 1998. Mineral evolution of acid forest soils in the Strengbach catchment (Vosges Mountains, N-E France). Geoderma, 82, 315-340.

Kaar, E. 1968. Über die Ausforstung von Ölschiefertagebauen. In Metsanduslikud uurimused, VI, pp. 20-30. Valgus, Tallinn.

Kaar, E. 1998. Rekultiveerimine Eestis. In Teaduse ajaloo lehekülgi Eestist. Vol. XII. Metsateaduse ajaloost Eestis (Meikar, T., comp.), pp. 175-193. TA Kirj., Tallinn.

Kaar, E., Lainoja, L., Luik, H., Raid, L. \& Vaus, M. 1971. Põlevkivikarjääride rekultiveerimine. Valgus, Tallinn.

Makhonina, G. I. 1974. Humus composition of soils, developed on the quarry detritus of lignite open-cast mining as a result of natural formation of plant cover. In Problems of Land Rehabilitation in the USSR, pp. 205-209. Novosibirsk (in Russian). 
Makhonina, G. I. 1979. Initial processes of soil formation on the cover detritus of Lipovsk nickel deposit. In Soil Formation in Technogenic Landscapes, pp. 123-140. Novosibirsk (in Russian).

McSweeney, K. \& Jansen, I. J. 1984. Soil structure and associated rooting behaviour in minesoils. Soil Sci. Soc. Am. J., 48, 607-612.

Ponomareva, V. V. 1957. To the method for the study of soil humus after I. V. Tyurin's scheme. Pochvovedenie (Sov. Soil Sci.), 8, 66-71.

Ranst, E. van, Verloo, M., Demeyer, A. \& Pauwels, J. M. 1999. Manual for the Soil Chemistry and Fertility Laboratory. Analytical Methods for Soils and Plants, Equipment and Management of Consumables. University of Ghent, Gent, Belgium.

Reintam, L. \& Kaar, E. 1999. Development of soils on calcareous quarry detritus of open-pit oilshale mining during three decades. Proc. Estonian Acad. Sci. Biol. Ecol., 48, 251-266.

Reintam, L., Kaar, E. \& Rooma, I. 2000. Formation and progress of soil organic matter under pine on quarry detritus of open-cast oil-shale mining. In Managing Forest Soils for Sustainable Productivity, pp. 235-236. Soc. Portuguesa da Ciencia do Solo, Vila Real, Portugal.

Roberts, J. A., Daniels, W. L., Bell, J. C. \& Burger, J. A. 1988. Early stages of mine soil genesis in a Southwest Virginia spoil lithosequence. Soil Sci. Soc. Am. J., 52, 716-723.

Rumpel, C., Knicker, H., Kögel-Knabner, I., Skjemstad, J. O. \& Hüttl, R. F. 1998. Types of chemical composition of organic matter in reforested lignite-rich mine soils. Geoderma, 86, 123-142.

Schafer, W. M., Nielsen, G. A. \& Nettleton, W. D. 1980. Minesoil genesis and morphology in a spoil chronosequence in Montana. Soil Sci. Soc. Am. J., 44, 802-807.

Taranov, S. A. \& Komissarov, I. D. 1974. Initial processes of soil formation on the quarry detritus of Pervouralsk iron ore deposit. In Problems of Land Rehabilitation in the USSR, pp. 209-215. Novosibirsk (in Russian).

Thimonier, A., Dupouey, J.-L. \& Le Tacon, F. 2000. Recent losses of base cations from soils of Fagus sylvatica L. stands in Northeastern France. Ambio, XXIX, 314-321.

Uzhegova, I. A. \& Makhonina, G. I. 1984. Initial stages of pedogenesis on the wastes of Pervouralsk iron ore deposit. Pochvovedenie (Sov. Soil Sci.), 11, 14-21.

Vaus, M. 1970. Eesti põlevkivikarjääride pinnaste metsakasvatuslikud omadused. Valgus, Tallinn.

Vaus, M. 1975. Role of oil shale in the soil-forming process and its effect on the growth of tree plants. In Metsanduslikud uurimused (Forestry Researches), XII, 154-164. Valgus, Tallinn.

\section{KORESELISE KARJÄÄRIPUISTANGU LÕIMISE JA NEELAMISOMADUSTE MUUTUMINE METSA ALL KOLME AASTAKÜMNE JOOKSUL}

\section{Loit REINTAM}

Koreselistel karjääripuistangutel (korest $450-650 \mathrm{~g} \mathrm{~kg}^{-1}$ ) Sirgalas KirdeEestis on kolmekümne aasta jooksul üheaegselt kõrgproduktiivsete männipuistutega moodustunud ja kiiresti arenenud $\mathrm{O} 2-\mathrm{A}-\mathrm{AC}-\mathrm{BC}$ profiiliga rähksed rendsiinad (Calcaric Regosol). Juurejäänustest ja metsakõdust tekkinud $\mathrm{R}_{2} \mathrm{O}_{3^{-}}$ humaat-fulvaatne huumus sisaldab õhukeses huumushorisondis $28 \pm 6 \mathrm{~g} \mathrm{~kg}^{-1}$ ja üleminekulises AC-horisondis $13 \pm 3 \mathrm{~g} \mathrm{~kg}^{-1}$ orgaanilist süsinikku. Suur on ka savi ja liikumatute poolteisthapenditega seotud huumusainete osakaal. Kujune- 
nud taimne metsahuumus on aktiivne ning lahustuvaid fraktsioone on $60-80 \%$ selle üldhulgast. Huumusainete ja puistangu mineraalosa vastastikmõjude tulemusel on kivid, kruusa- ja liivafraktsioonid tõhusalt murenenud ning savi ja tolm kogunenud vastavalt protsessi käigus kujunenud huumushorisondis ja selle all olevas üleminekuhorisondis. Õhukeses kihis sügavuti hoogustuv füüsikaline ning sellega kaasuv ja järgnev keemiline murenemine haarab kõiki granulomeetrilisi fraktsioone. Samas on lõimise muutuste horisontaalne (territoriaalne) varieerumine väiksem kui mullatekke orgaanilistel mõjustajatel - huumusainetel. $\mathrm{Ca}^{2+}$ moodustab üle $80 \%$ neelamismahutavusest, $\mathrm{Mg}^{2+}$ aga on kõige varieeruvam komponent neelavas kompleksis. Neeldunud $\mathrm{H}^{+}$ja $\mathrm{Al}^{3+}$ puuduvad sootuks ning savi ja neeldunud aluste suhtes akumulatiivseid primaarseid rendsiinasid iseloomustab nõrgalt leelisene reaktsioon. Metsavaris ja -kõdugi on vaid nõrgalt happelised. Ehkki huumuskolloidid on neelavas kompleksis valdavaiks, kuulub tähtis koht ka mullatekkes moodustunud saviosakestele. 